\title{
Demonetization in India: Its Effects on Economy and its Success in Getting Rid of Black Money
}

\author{
Udhava Gupta
}

\begin{abstract}
Narendra Modi, the prime minister of India, on 8th November 2016, took a bold decision of demonetization of 500 and 1000 Rupees currency notes. The purpose of demonetization was to fight the prevalent black money market of India, but it had various unforeseen outcomes that went against what was ideally planned. This study will help us understand the real intention behind demonetization. Its short and long term effects on the Indian economy and to what extent was it a success in getting rid of black money. This study adopts a pragmatic approach, that's both descriptive and analytical, based on secondary data to find the real effects of demonetization on the Indian economy. Demonetization turned out to be a disaster for the Indian Economy as it was not able to tackle the black market; instead it put the Indian economy in jeopardy, both, in long and short run.
\end{abstract}

Index Terms - Demonetization, Black money, Government, Cashless economy, financial strategy.

\section{INTRODUCTION}

Demonetization has been a controversial topic of discussion in the economic world whenever it has surfaced from time to time. Started in 1892, demonetization was first time practiced in Ghana when 50-cedi currency note was demonetized. Countries like Australia, India, Myanmar, Soviet Union, North Korea; Zimbabwe etc. have previously practiced demonetization at some point [1]. Basically, demonetization is the act of stripping a currency unit of its status as legal tender. Demonetization is a big step taken by officials as it is a drastic change nationwide undertaken overnight and can throw off the economies easily if not planned and executed well. Usually, Demonetization is undertaken by nations for a number of reasons ranging "to combat inflation, to combat corruption and crime, to combat counterfeiting and tax evasion, to discourage a cash-dependent economy and to facilitate trade". In this paper, I will be discussing the specific case of demonetization of currency in India, the motivation behind it and will be evaluating the extent of success it achieved.

\section{DISCUSSION}

India is one of the most fast developing economies in the world because of which it faces a lot of problems if we talk about from an economic prospective. With a population of 1.25 billion people, it is the second most populated nation in the world. Yet only 30 million people file taxes and only $22 \%$ of people have credit or ATM cards [2] The primary source of

Udhava Gupta, $12^{\text {th }}$ Student, Neerja Modi School, Jaipur capital used for transaction every day is tender cash. This although not being a bad thing of its own, the prominence of cash as a mode for day-to-day transaction can have its own disadvantages. Counterfeited currency is easy to spread and can prove to be a poison for the nation's economy. Also, as cash transactions can be made without any record, it leads to huge sum of money not going to the government as taxes due to tax evasion. To combat these problems, the Prime Minister of India, Mr. Narendra Modi, made an announcement on November 8, 2016 to the citizenry that Indian government has decided to demonetize the notes of rupees five hundred and rupees one thousand which amounted for about $86.2 \%$ of the country's circulating cash [3]. These notes were left valueless applicable instantaneously and people were given a time period of 62 days to replace them with the new currency notes of Rupees 2000 and 500.

Interestingly, this was not the first-time demonetization was practiced in India. A year and a half before it's independence notes of rupees 5,000 and 10,000 were rendered useless as a mode of exchange, same was done for a second time when 1,000 and 5,000- rupee notes were pulled out of circulation in 1977. Both the times before, the demonetization efforts did not reap the results that were expected of. Failure in planning and execution and the presence of bureaucracy is always accounted as the reason behind failure in achieving success for these attempts. But if thought about it, there is only some much there can be done planning the project. Demonetization can only be successful if no one sees it coming. If people who are involved in tax evasion or have black money in form of cash even get a slightest of idea about demonetization, they will come up with some scheme to protect their illegal savings. Therefore, it is necessary for demonetization to be brought into effect overnight. And when the timeframe of execution is so small, the execution never goes well. The November 2016 attempt made by Modi had the same problem with the same effects.

By rendering of 1,000- and 500-rupee note worthless, the whole Indian economy went into a state of panic. This withdrawal of notes accounted for $86 \%$ of circulating currency in a country where large percentage of transactions are cash-based [4]. The new rupee notes were not distributed while the old ones were sent out of circulation. Due to the shock, each and every person rushed to the nearest banks to get the new bills, leading to the overload of demand of new bills. This lead to a state where 2 to 3-mile-long lines of people waiting from dusk to dawn could be seen in front of each and every bank. Even the ATM's were rendered useless as they were calibrated to the size of old notes, which was 
changed by the issue of new currency. Ultimately, people were forced to use the small bills such as 10-, 20- or 50- rupee notes, which hold little to no value. Even enough food cannot be bought with such low bills. People were left in a very difficult stage, which forced many to ask the question, was it, the right time and were the intended people affected?

If we talk about the timing of the project, there is no definitive answer if it was right or not. There is no particular estimate made about the amount of black money present in India right now, but it will be safe to say that the amount will be increasing per day, not decreasing by any chance. So, implementing the plans would make a sense at any given point. As there is no time period when black money is more present than other times, demonetizing any time would make sense. If we talk about people who were affected by the project, I don't think that the people who were intended to be affected experienced the problem. On the other hand, common population suffered a lot during the first two months of demonetization. This is because usually people who practice tax evasion or are involved in black money are powerful and have resources, which they could use to make the most from what they have. On the other hand, common folks with normal day-to-day life were even struggling for survival [2]. As all the big bills were rendered worthless, even buying food and paying electric and water bills was getting difficult. People were literally scrapping every coin or small note to collect as much as they could. And especially people who had events planned such as marriages for their daughters or school fees to pay, they were left helpless. So, it could be argued that it hurt the common people more than it healed the nation.

If we talk about the success of the project, I personally wouldn't consider this as a successful project. Although, it did strike some fear in the hearts of the wrongdoers that things are not going to be simple as before and any day something could happen that will put a halt on their evil deed. Thousands of people were arrested and the government in the process confiscated billions of rupees. But this is not the full picture. Statistically speaking, over 3 trillion rupees, or over \$44 billion in old currency, were deposited with Indian banks in just the first week after the demonetization [5]. The number of income tax returns filed for 2016-2017 financial year grew by $25 \%$. According to the annual report from the Reserve Bank of India (RBI), the country's central bank, found that a total of 15.28 trillion rupees ( $\$ 239$ billion) worth of cancelled high-value notes were deposited or exchanged for new money in the 10 months since the strategy was implemented. But this should not be considered as success as it was drafted on the incorrect premise that black money means cash. It was thought that if cash were squeezed out, the black economy would be eliminated, which is totally wrong. "That's because people don't stack black money in cash. Rather, they stash it in undisclosed accounts in Swiss Banks. So, the demonetization won't affect the biggest fish" [6]. This is absolutely true as cash is only one component of black wealth, around $1 \%$ to be precise. It has now been confirmed that $98.8 \%$ of demonetized currency had come back to the Reserve bank of India. Further, of the 160 billion that is still out, most of it is accounted for. "In brief, not even $0.01 \%$ of black money has been extinguished" [2].

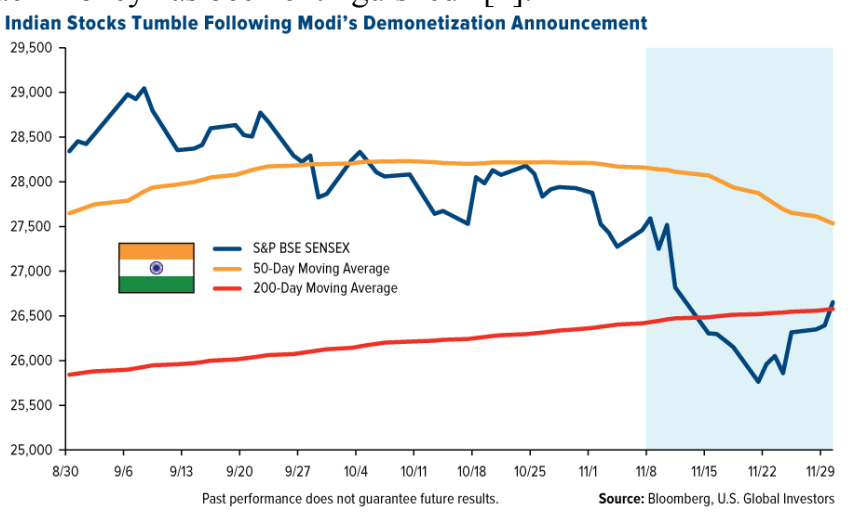

Fig. 1 Indian Stocks Tumble Post Demonetization

\section{EVALUATION}

When the government started receiving backlash after the disclosure of these statistical figures by the Reserve bank and other economical agencies, the government changed its final objective saying that it is good that black money has been deposited in international banks because "those depositing it now can be caught" [7]. Then the government suggested that the real aim of the demonetization was a cashless society. By undergoing demonetization, it says that idle money came into the system, the cash-to-GDP ratio has and will decline and the tax base will expand [5] Further, anticipating the failure of demonetization in 2016 itself, the government started saying that demonetization is one of the many steps to tackle the black economy [2].

One other thing to take into consideration is that government didn't even discuss what effects demonetization would have on the 'non-black' Indian economy. When demonetization plan was implemented, rupee dropped to its all-time low value of the year at $0.0145 \$$ per rupee. Demonetization wrecked the primarily cash-reliant rural economy, adding distress to mounting debts. The agricultural sector, which is behind in reforms and investment, worsened due to cash shortages, plunging demand and collapsing prices. Prices of potatoes, onions and tomatoes were half of what they had been a year before in January-February. Production took a hit too, accompanied by fall in employment, wages and job losses in the two months after demonetization. In Mumbai, more than $50 \%$ of the power loom units were shut down, impacting around 300,000 workers. Around 1.5 million jobs were lost in the first four months of this year. The economy is also still coping with aftermath. In the first quarter of fiscal 2017- 18, growth slumped to $5.7 \%$ compared to $7.1 \%$ in the same quarter of the previous year [8]. 


\section{Indian shares have fallen slightly more than other Asian markets}

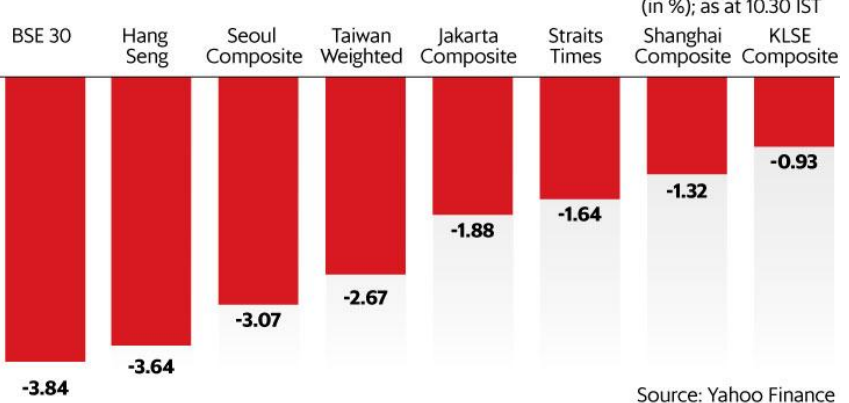

\section{The real impact of the demonetisation process is seen in mid-and small sized stocks and some sectoral indices}

(in \%); as at 10.35 IST

\begin{tabular}{l|ll} 
BSE Realty & -15.1 & \\
\hline BSE Consumer Durables & -8.2 \\
\hline BSE Smallcap & \multicolumn{2}{l}{} \\
\hline BSE Midcap & -6.8 \\
\hline BSE Consumer Discretionary & -6.1 \\
\hline BSE 500 & -5.9 \\
\hline Sensex & -4.9 \\
\hline
\end{tabular}

Source: bseindia.com

Fig. 2 Impact of Demonetization on mid and small sized stocks

\section{CONCLUSION}

One other side of the picture, which was ignored but is important is politics. It would not be wrong to say that the whole demonetization scheme did help Bhartiya Janta Party (BJP), the political party to which Prime Minister Narendra Modi belongs to, to gain a strong footing for the oncoming elections that year. "The drama of demonetization allowed Prime Minister Narendra Modi to demonstrate in a very visible way his commitment to fighting corruption and black money." Prior to the data release, it was unclear how successful Modi's policy had been, and as such his political motives were enough to win him favor with India's vast segment of poorer voters at the polls. BJP won overwhelming support in March elections in Uttar Pradesh, India most populous and one of its poorest states. "The government and its supporters can argue that even if demonetization failed to remove black money from circulation, that at least Modi and the government tried to do something about it" [7]. As said by New York-based South Asia-focused Eurasia Group analyst Sasha Riser-Kositsky "It's important to remember that the demonetization move was intended more as a political move than as an economic one" [2]. All in all, demonetization accomplished too little while causing too much collateral damage. But despite economic toll, it gained a little bit as it's side effects. I personally would not consider demonization as a suitable way to fight black Money. It caused too much pain to the innocent people and too little to the deserving ones. At the same time, the money India gained from the seizure of whatever black money was presented was too little as compared to the money it lost due to the economy going down. I wouldn't say it was worth it and a lot better could have been done to achieve the final goals.

\section{ACKNOWLEDGMENT}

This research was partially supported by Mr. Paresh Gupta, Dean, Global Centre for Entrepreneurship and Commerce. I thank my colleagues from various institutions of Jaipur, Spain, Massachuessetts, New York for providing meaningful insights through spirited discussions.

I thank Meesha Gupta for taking out time from her hectic schedule at Union College, New York and helping me gain a better understanding of research and facilitated my growth as a researcher.

I would also like to show my gratitude to Ms. Shiromi Chaturvedi, for being my mentor and research guide throughout the arduous process of research and publication.

My acknowledgments would be incomplete without expressing gratitude to my alma mater, Neerja Modi School, Jaipur which has been the pillar of my knowledge over these years.

\section{REFERENCES}

[1] G. O. Young, "Synthetic structure of industrial plastics (Book style with paper title and editor)," in Plastics, 2nd ed. vol. 3, J. Peters, Ed. New York: McGraw-Hill, 1964, pp. 15-64.

[2] W.-K. Chen, Linear Networks and Systems (Book style). Belmont, CA: Wadsworth, 1993, pp. 123-135.

[3] H. Poor, An Introduction to Signal Detection and Estimation. New York: Springer-Verlag, 1985, ch. 4.

[4] B. Smith, "An approach to graphs of linear forms (Unpublished work style)," unpublished.

[5] E. H. Miller, "A note on reflector arrays (Periodical style-Accepted for publication)," IEEE Trans. Antennas Propagat., to be published.

[6] J. Wang, "Fundamentals of erbium-doped fiber amplifiers arrays (Periodical style-Submitted for publication)," IEEE J. Quantum Electron., submitted for publication.

[7] C. J. Kaufman, Rocky Mountain Research Lab., Boulder, CO, private communication, May 1995.

[8] Y. Yorozu, M. Hirano, K. Oka, and Y. Tagawa, "Electron spectroscopy studies on magneto-optical media and plastic substrate interfaces(Translation Journals style)," IEEE Transl. J. Magn.Jpn., vol.

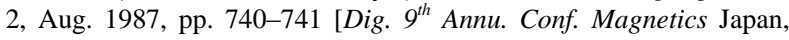
1982, p. 301].

[9] M. Young, The Techincal Writers Handbook. Mill Valley, CA: University Science, 1989.

[10] (Basic Book/Monograph Online Sources) J. K. Author. (year, month, day). Title (edition) [Type of medium]. Volume(issue). Available: http://www.(URL)

[11] J. Jones. (1991, May 10). Networks (2nd ed.) [Online]. Available: http://www.atm.com

[12] (Journal Online Sources style) K. Author. (year, month). Title. Journal [Type of medium]. Volume(issue), paging if given. Available: http://www.(URL)

[13] R. J. Vidmar. (1992, August). On the use of atmospheric plasmas as electromagnetic reflectors. IEEE Trans. Plasma Sci. [Online]. 21(3). pp. $876-880 . \quad$ Available: http://www.halcyon.com/pub/journals/21ps03-vidmar 